\title{
Proline-Modified DNA as Catalyst of the Aldol Reaction**
}

\author{
Zhuo Tang and Andreas Marx*
}

\author{
Dedicated to Professor Peter Welzel on the occasion of his 70th birthday
}

DNA templated synthesis has emerged as a powerful tool to steer reactivity by modulating nature's approach to increase the effective molarity of the reactants. ${ }^{[1]}$ By making recourse to the inherently selective duplex formation properties of cognate DNA strands, small molecule reactants are brought to close proximity increasing the effective molarity and thereby significantly accelerating chemical reactions. Several applications of this approach have been developed such as compound discovery from synthetic libraries, reaction dis covery, and nucleic acid sensing. ${ }^{[1,2]}$ Additionally, these kinds of reactions were suggested to serve as model systems demonstrating how nucleic acids can catalyze chemical reactions and thus, implicating their role as catalysts in an early stage in the history of life on earth. ${ }^{[3,4]}$

All of the depicted approaches have in common that the two reactants are covalently linked to two DNA or PNA strands that are subsequently allowed to react by self hybridization or alignment through hybridization with a third nucleic acid strand. This design results in covalent interconnection of the two modified oligonucleotides in most cases with only few exceptions. ${ }^{[1,2,5]}$ Along these lines, a DNA templated ester hydrolysis promoted by a $\mathrm{Cu}^{\mathrm{II}}$ catalyst was reported as well as a DNA templated Staudinger ligation reaction. ${ }^{[5 e, f]}$ In these cases a non tethered reagent (i.e. water) reacted with a DNA tethered reagent by DNA templation. We intended to expand the scope of DNA templated syn thesis using non tethered reagents. Herein we report on a new approach that enables the cross aldol reaction of a DNA tethered aldehyde with free non tethered ketones. Our approach is based on the covalent attachment of a catalyst to an oligonucleotide complementary to a DNA tethered aldehyde component.

Recently, the field of organocatalysis has gained much attention in the chemical research community. ${ }^{[6]}$ Numerous small organic compounds were found to achieve remarkably selective and efficient transformations. As one of the most important components of organocatalysts, proline ${ }^{[7 a \mathrm{~b}]}$ and its derivatives ${ }^{[7 \mathrm{c} \mathrm{f}}$ have been shown to possess the extraordinary ability to catalyze for example, the aldol reaction via an

[*] Dr. Z. Tang, Prof. Dr. A. Marx

Department of Chemistry

University of Konstanz

Universitätsstrasse 10, 78457 Konstanz (Germany)

Fax: (+49) 7531885140

Email: andreas.marx@uni konstanz.de

$[* * *$ We gratefully acknowledge the award of a fellowship to Z.T. by the Alexander von Humboldt Foundation. enamine intermediate. We reckoned that a proline attached to one DNA strand might act as a catalyst for the cross aldol reaction between an aldehyde tethered to a complementary DNA sequence and a non tethered ketone. It should be noted that aqueous buffer conditions required for most DNA templated reactions still represent a challenge for organo catalysis. ${ }^{[8]}$ Though there are two reports about DNA templated aldol reactions, ${ }^{[4,9]}$ our approach differs concep tually due to the covalent attachment of the catalyst and a reaction partner that is not bound to DNA.

We first synthesized the oligonucleotide template $\mathbf{1}$, which bears a conjugated aldehyde at its $3^{\prime}$ terminus, and a complementary strand $\mathbf{2}$, which contains a proline moiety at its $5^{\prime}$ terminus (Figure 1). ${ }^{[10]}$ Subsequently, we tested the
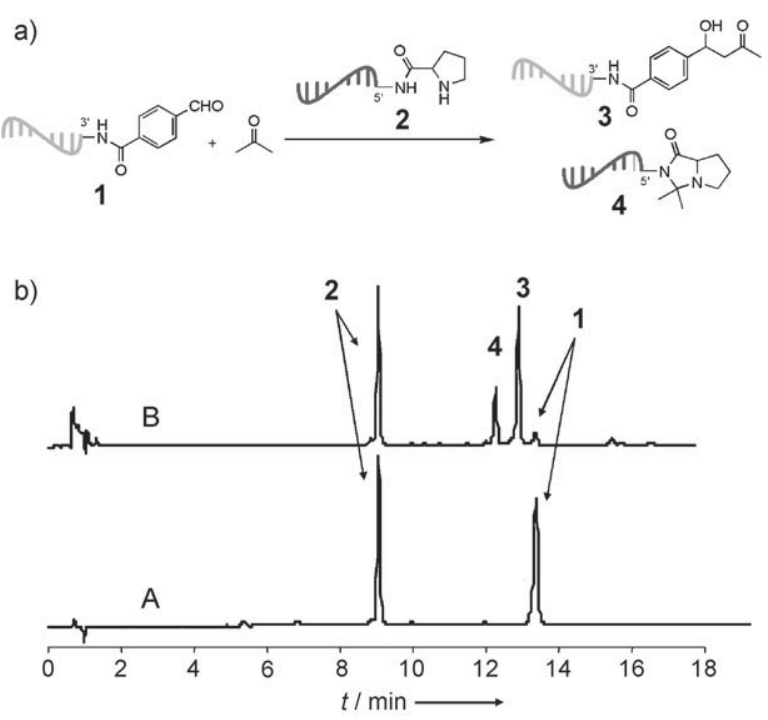

Figure 1. a) DNA templated cross aldol reaction catalyzed by prolina mide 2. b) A) HPLC analysis of the reaction mixture of $\mathbf{1}$ and $\mathbf{2}$ in $100 \mathrm{~mm}$ phosphate buffer ( $\mathrm{pH}$ 7.2) without addition of acetone. B) HPLC analysis of the reaction between 1 and acetone catalyzed by 2 after $4 \mathrm{~h}$ in $100 \mathrm{~mm}$ phosphate buffer $\left(\mathrm{pH} \mathrm{7.2)}\right.$ at $25^{\circ} \mathrm{C}$. Phosphate buffer: $\mathrm{Na}_{2} \mathrm{HPO}_{4} / \mathrm{NaH}_{2} \mathrm{PO}_{4}$. The reaction was performed in aqueous buffer/acetone (v/v 4:1).

catalytic ability of the prolinamide $\mathbf{2}$ in the reaction between acetone and $\mathbf{1}$ initially at $\mathrm{pH} 7.2$ in an aqueous buffer. The reactions were analyzed by denaturing $\mathrm{HPLC}^{[11]}$ at $50^{\circ} \mathrm{C}$ to obtain the required resolution. The signals were assigned to the respective entities by ESI MS analysis. ${ }^{[10]}$ Much to our delight we discovered that the desired product of a cross aldol reaction of the DNA tethered aldehyde $\mathbf{1}$ and acetone is formed in high yields (Figure 1). The disappearance of the signal for $\mathbf{1}$ was observed as well as the appearance of signals 
for two new reaction products. One was identified by ESI MS to be the desired product 3 . The by product is suggested to be 4, which can be explained by condensation of $\mathbf{2}$ with acetone. $^{[12]}$

Encouraged by these initial findings we further optimized the reaction conditions and found $\mathrm{pH} 7.08 .0$ in $200 \mathrm{~mm}$ phosphate buffer to be best suited for our approach. To verify that the observed results are indeed caused by proline catalysis we investigated the formation of product $\mathbf{3}$ upon addition of several oligonucleotide constructs in a time dependent manner (Figure 2, Table 1). When unmodified

a)
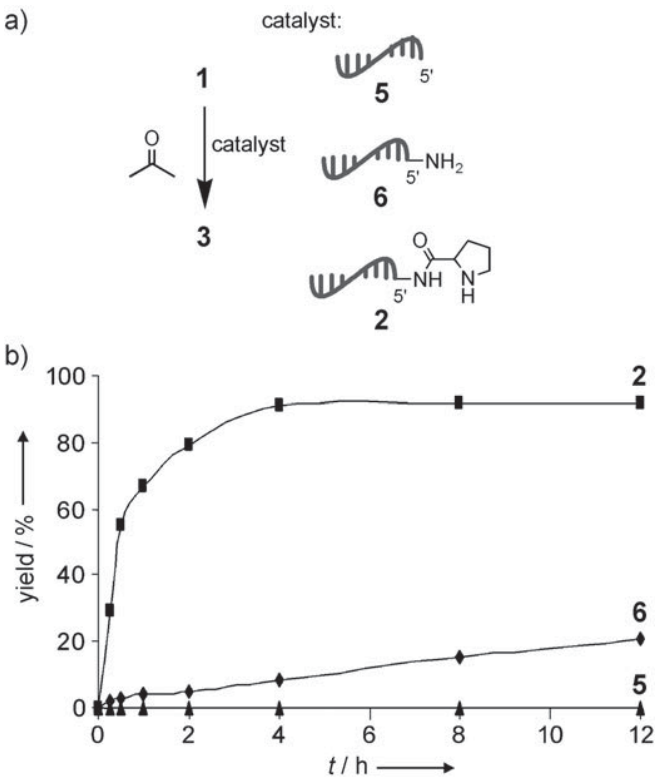

Figure 2. a) Catalysis of a cross aldol reaction by different DNA constructs. b) Time dependent formation of reaction products cata lyzed by various DNA constructs.

Table 1: Cross aldol reaction catalyzed by different catalysts.

\begin{tabular}{llcc}
\hline Entry & Catalyst $^{[a]}$ & $t[\mathrm{~h}]$ & Yield 3 [\%] \\
\hline 1 & 5 & 24 & $<5$ \\
2 & 6 & 24 & 40 \\
3 & 2 & 4 & 92 \\
4 & $2^{[b]}$ & 4 & 92 \\
5 & 4 & 24 & $<5$ \\
6 & prolinamide $^{[\mathrm{c}]}$ & 4 & 6 \\
7 & prolinamide $^{[\mathrm{d}]}$ & 4 & 15 \\
\hline
\end{tabular}

[a] Conditions: The concentration of oligonucleotides is $3 \mu \mathrm{M}$ in $100 \mathrm{~mm}$ phosphate buffer $(\mathrm{pH} 7.2)$ and the ratio of aqueous buffer/acetone is $5: 1$ $(\mathrm{v} / \mathrm{v})$. The reactions were incubated at $25^{\circ} \mathrm{C}$. [b] The concentration of oligonucleotides is $0.3 \mu \mathrm{m}$. [c] The concentration of prolinamide is $0.3 \mathrm{~mm}$. [d] The concentration of prolinamide is $3.0 \mathrm{~mm}$.

oligonucleotide $\mathbf{5}$, which is complementary to $\mathbf{1}$, was used, the formation of the desired reaction product $\mathbf{3}$ was below the detection limit within $24 \mathrm{~h}$ (Table 1 , entry 1 ). Interestingly, the DNA linked primary amine $\mathbf{6}$ could also promote the cross aldol reaction in about $40 \%$ yield after $24 \mathrm{~h}$ (Table 1 , entry 2 ). Nevertheless, the proline modified DNA 2 gave 3 in $92 \%$ yield already after $4 \mathrm{~h}$ (Figure 2 and Table 1, entry 3 ), indicating that the efficiency of $\mathbf{6}$ to promote the reaction is considerably lower. Comparison of the initial rates revealed that the reaction promoted by $2\left(243 \times 10^{-11} \mathrm{M} \mathrm{s}^{-1}\right)$ is about 170 times faster than the one promoted by $\mathbf{6}(1.43 \times$ $\left.10^{-11} \mathrm{M} \mathrm{s}^{-1}\right) \cdot{ }^{[10]}$ Even diluting the reactants $\mathbf{1}$ and $\mathbf{2}$ by tenfold resulted in the same yield (Table 1, entry 4). Poor efficiency was observed when the by product $\mathbf{4}$ was employed to catalyze the reaction (Table 1 , entry 5 ). In contrast to the high proficiency of the oligonucleotide conjugate $\mathbf{2}$ to promote the reaction, non DNA conjugated prolineamide was a poor catalyst of this reaction (Table 1, entries 6 and 7).

Next we investigated the scope of the reaction. We found that DMSO is the best cosolvent for ketones insoluble in water. Moderate to high yields were obtained when DNA templated prolinamide $\mathbf{2}$ was used to catalyze the cross aldol reaction between oligonucleotide $\mathbf{1}$ and different ketones (Figure 3). Thus, employing the DNA templated prolinamide 2, different cross aldol reactions can be performed starting from DNA conjugated aldehyde $\mathbf{1}$. However, the initial rates were lower than the one observed for the reaction with acetone.

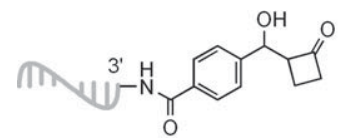

$68.5 \times 10^{-11} \mathrm{M} \mathrm{s}^{-1}(95 \%)$

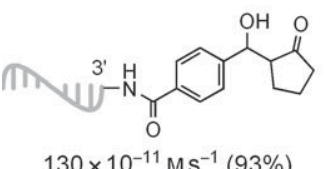

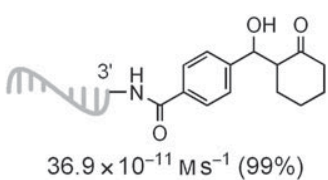

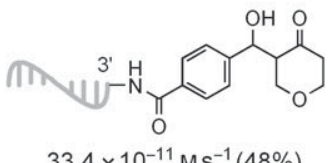

Figure 3. Cross aldol products of 1 and different ketones catalyzed by 2. The concentration of oligonucleotides is $3 \mu \mathrm{M}$ in $100 \mathrm{~mm}$ phosphate buffer $(\mathrm{pH} \mathrm{8.0)}$ and 30:10:3 (v/v/v) of aqueous phase/DMSO/ketone. Initial rates and yields are given.

Only a few examples are reported in which catalytic turnover could be achieved in DNA templated reactions. ${ }^{[13]}$ We expected that the herein depicted reaction is highly unlikely to proceed with catalytic turnover when substoichio metric amounts of $\mathbf{2}$ are used because of the formation of the bicyclic imidazolidinone $\mathbf{4}$ that inactivates the catalyst (Table 1, entry 5). To address this shortcoming, modified oligonucleotide $\mathbf{7}$ was synthesized. Construct $\mathbf{7}$ comprises two proline moieties connected through a peptide bond. The formation of an imidazolidinone should be suppressed due to the absence of an amide proton in the $\gamma$ position to the $\mathrm{N}$ atom involved in enamine formation. Indeed, this was achieved without formation of significant amounts of by product when $\mathbf{1}$ was allowed to react with acetone in the presence of $\mathbf{7}$ (Figure 4).

The initial rate $\left(41.2 \times 10^{-11} \mathrm{M} \mathrm{s}^{-1}\right)$ of the reaction pro moted by $\mathbf{7}$ was lower than the one promoted by $\mathbf{2}$ but nevertheless, afforded the desired product in excellent yield (Table 2, entry 1). We next investigated whether 7 was able to promote the reaction in substoichiometric amounts, and 
a)
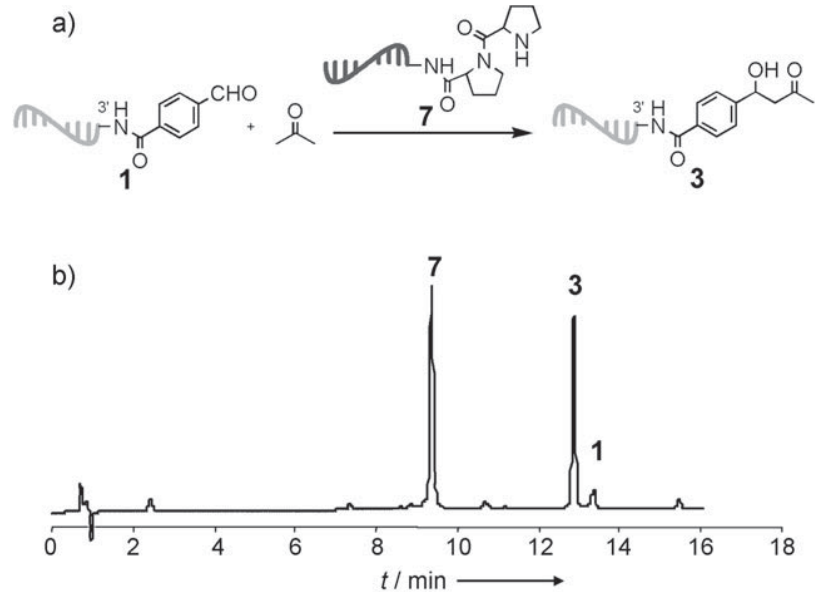

Figure 4. a) DNA templated cross aldol reaction between 1 and ace tone catalyzed by prolinamide 7. b) Denaturing HPLC analysis of reaction products.

Table 2: Cross aldol reaction catalyzed by oligonucleotide 7 .

\begin{tabular}{llll}
\hline entry & $\mathbf{7}\left[\mathrm{mol}_{0}\right]^{[\mathrm{a}]}$ & $t[\mathrm{~h}]$ & Yield [\%] \\
\hline 1 & 100 & 24 & 93 \\
2 & 10 & 24 & 26 \\
3 & 10 & 48 & 34 \\
4 & 10 & 72 & 41
\end{tabular}

[a] The concentration of oligonucleotide 1 is $3 \mu \mathrm{m}$ in $100 \mathrm{~mm}$ phosphate buffer $(\mathrm{pH} 7.3)$ at $25^{\circ} \mathrm{C}$. The ratio of aqueous buffer/acetone is $5: 1(\mathrm{v} / \mathrm{v})$.

found that it could (Table 2, entries 2 4). With $10 \mathrm{~mol} \%$ of $\mathbf{7}$, the reaction between oligonucleotide $\mathbf{1}$ and acetone gave the desired product in $41 \%$ yield after $72 \mathrm{~h}$.

One can envision that the low turnover results from the formation of a stable duplex of the catalyst $\mathbf{7}$ and the reaction product $\mathbf{3}$ and subsequent sluggish strand exchange of $\mathbf{3}$ with reactant 1 . We envisaged that strand exchange might be promoted by cycling the ambient temperature between $25^{\circ} \mathrm{C}$ (reaction temperature) and $80^{\circ} \mathrm{C}$ (duplex denaturation tem perature), since the melting temperature $\left(T_{\mathrm{m}}\right)$ for the strand comprising $\mathbf{1}$ and $\mathbf{7}$ is $63^{\circ} \mathrm{C} \cdot{ }^{[10]}$ When annealing by cooling from $80^{\circ} \mathrm{C}$ to $25^{\circ} \mathrm{C}$, unreacted $\mathbf{1}$ will initially (when present in higher concentration than product 3 ) have an increased probability to anneal to catalyst $\mathbf{2}$. Thus, product formation should be favored until the system reaches equilibrium. Indeed we found that the turnover numbers can be increased significantly by temperature cycling (Table 3 ). When the

Table 3: Cross aldol reaction catalyzed by oligonucleotide 7 employing temperature cycling.

\begin{tabular}{llll}
\hline Entry & $\mathbf{7}\left[\mathrm{mol}^{[]^{\text {a] }}}\right.$ & Cycles & Yield [\%] \\
\hline 1 & 10 & 25 & 56 \\
2 & 10 & 50 & 71 \\
3 & 5 & 25 & 41 \\
4 & 5 & 50 & 53 \\
5 & 0 & 50 & 14 \\
\hline
\end{tabular}

[a] Cycling was performed by employing the following program: reaction at $25^{\circ} \mathrm{C}$ for $1 \mathrm{~h}$, followed denaturation at $80^{\circ} \mathrm{C}$ for $1 \mathrm{~min}$. catalysts loading was $10 \mathrm{~mol} \%$ and the reaction was cycled 25 times the yield was increased compared to the outcome of the reaction when isothermal reaction conditions were applied (see Table 2, entries 24 and Table 3, entry 2). This yield could be increased to $71 \%$ when the number of cycles was increased (Table 3, entry 2). Notably, when the reaction was conducted under isothermal conditions at $80^{\circ} \mathrm{C}$ for $1 \mathrm{~h}$ in the absence of 7 only a poor yield of $14 \%$ was achieved. Thus, this rules out that the higher yield observed in the cycled reactions derives from higher reaction times at the increased reaction temperature. The catalyst loading could be further decreased to $5 \mathrm{~mol} \%$ and yet turnover could still be detected resulting in significant product formation.

In summary, we show that a proline tethered to a DNA strand can efficiently catalyze the cross aldol reaction of a complementary DNA aldehyde conjugate with non tethered ketones. The developed system is able to catalyze the aldol reaction between a DNA tethered aldehyde and several ketones thereby tolerating DMSO as co solvent in cases where water insoluble ketones were employed. Interestingly, through optimization of the proline catalyst design a species was derived that was able to achieve catalytic turnover. The turnover numbers could be increased by cycling the ambient temperature between the reaction temperature and the DNA duplex denaturation temperature. Our finding that DNA tethered prolines even catalyze intermolecular aldol reactions between tethered and non tethered reactants adds extends the methodological repertoire of DNA templated reactions.

Received: April 2, 2007

Revised: June 16, 2007

Published online: August 17, 2007

Keywords: aldol reaction. DNA templated synthesis . organocatalysis · prolinamide

[1] a) X. Li, D. R. Liu, Angew. Chem. 2004, 116, 4956; Angew. Chem. Int. Ed. 2004, 43, 4848; b) J. B. Doyon, T. M. Snyder, D. R. Liu, J. Am. Chem. Soc. 2003, 125, 12372; c) Z. J. Gartner, M. W. Kanan, D. R. Liu, J. Am. Chem. Soc. 2002, 124, 10304; d) Z. J. Gartner, B. N. Tse, R. Grubina, J. B. Doyon, T. M. Snyder, D. R. Liu, Science 2004, 305, 1601.

[2] A. P. Silverman, E. T. Kool, Chem. Rev. 2006, 106, 3775.

[3] a) W. Gilbert, Nature 1986, 319, 618; b) G. F. Joyce, Nature 2002 , $418,214$.

[4] M. Oberhuber, G. F. Joyce, Angew. Chem. 2005, 117, 7752; Angew. Chem. Int. Ed. 2005, 44, 7580.

[5] a) T. N. Grossmann, O. Seitz, J. Am. Chem. Soc. 2006, 128, 15596 ; b) N. Graf, M. Göritz, R. Krämer, Angew. Chem. 2006, 118, 4117; Angew. Chem. Int. Ed. 2006, 45, 4013; c) I. Boll, R. Krämer, J. Brunner, A. Mokhir, J. Am. Chem. Soc. 2005, 127, 7849; d) J. Cai, X. Li, J. S. Taylor, Org. Lett. 2005, 7, 751; e) J. Cai, X. Li, X. Yue, J. S. Taylor, J. Am. Chem. Soc. 2004, 126, 16324; f) F. H. Zelder, J. Brunner, R. Krämer, Chem. Commun. 2004, 902; g) J. Brunner, A. Mokhir, R. Krämer, J. Am. Chem. Soc. 2003, 125, 12410; h) Z. Ma, J. S. Taylor, Bioorg. Med. Chem. 2001, 9, 2501; i) Z. Ma, J. S. Taylor, Proc. Natl. Acad. Sci. USA 2000, 97, 11159 .

[6] Recent reviews on organocatalysis, see: a) P. I. Dalko, L. Moisan, Angew. Chem. 2004, 116, 5248; Angew. Chem. Int. Ed. 2004, 43, 5138; b) J. Seayad, B. List, Org. Biomol. Chem. 2005, 3 , 
719; c) K. N. Houk, B. List, Acc. Chem. Res. 2004, 43, 5138; d) P. Kočovský, A. V. Malkov, Tetrahedron 2006, 62, 243 (Organo catalysis in Organic Synthesis).

[7] a) B. List, Acc. Chem. Res. 2004, 37, 548; b) W. Notz, F. Tanaka, C. F. Barbas III, Acc. Chem. Res. 2004, 37, 580; c) Z. Tang, Z. H. Yang, X. H. Chen, L. F. Cun, A. Q. Mi, Y. Z. Jiang, L. Z. Gong, J. Am. Chem. Soc. 2005, 127, 9285; d) Z. Tang, F. Jiang, X. Cui, L. Z. Gong, A. Q. Mi, Y. Z. Jiang, Y. D. Wu, Proc. Natl. Acad. Sci. USA 2004, 101, 5755; e) Z. Tang, Z. H. Yang, L. F. Cun, L. Z. Gong, A. Q. Mi, Y. Z. Jiang, Org. Lett. 2004, 6, 2285; f) H. Torii, M. Nakadai, K. Ishihara, S. Saito, H. Yamamoto, Angew. Chem. 2004, 116, 2017; Angew. Chem. Int. Ed. 2004, 43, 1983.

[8] a) T. J. Dickerson, K. D. Janda, J. Am. Chem. Soc. 2002, 124 3220 3221; b) N. Mase, Y. Nakai, N. Ohara, H. Yoda, K. Takabe, F. Tanaka, C. F. Barbas III, J. Am. Chem. Soc. 2006, 128, 734 c) A. P. Brogan, T. J. Dickerson, K. D. Janda, Angew. Chem. 2006, 118, 8278; Angew. Chem. Int. Ed. 2006, 45, 8100.
[9] M. M. Rozenman, D. R. Liu, ChemBioChem 2006, 7, 253.

[10] See Supporting Information for details.

[11] a) O. P. Josef, U. P. Anton, Patent US5795976, 1998; b) B. Wang, J. M. Sayer, H. Yagi, H. Frank, A. Seidel, D. M. Jerina, J. Am. Chem. Soc. 2006, 128, 10079.

[12] T. Polonski, Tetrahedron 1985, 41, 611. When recording the mass spectrum of the by product only $\mathbf{2}$ could be identified. We reason that the bicyclic imidazolidinone $\mathbf{4}$ was initially formed and decomposed under ESI MS conditions. However, we were able to identify by ESI MS the bicyclic imidazolidinone by products of reactions employing the ketones described in Figure 3.

[13] a) Z. Y. J. Zhan, D. G. Lynn, J. Am. Chem. Soc. 1997, 119, 12420; b) S. Sando, H. Abe, E. T. Kool, J. Am. Chem. Soc. 2004, 126, 1081; c) C. Dose, S. Ficht, O. Seitz, Angew. Chem. 2006, 118, 5495; Angew. Chem. Int. Ed. 2006, 45, 5369. 